\title{
Microbiome-Dependent Adaptation of Seaweeds Under Environmental Stresses: A Perspective
}

\author{
Fatemeh Ghaderiardakani', Maria Liliana Quartino² and Thomas Wichard ${ }^{1 *}$ \\ 1 Jena School for Microbial Communication, Institute for Inorganic and Analytical Chemistry, Friedrich Schiller University \\ Jena, Jena, Germany, ${ }^{2}$ Department of Coastal Biology, Argentinean Antarctic Institute, Buenos Aires, Argentina
}

OPEN ACCESS

Edited by:

Manoj Kumar

University of Technology Sydney,

Australia

Reviewed by:

Beata Iwona Messyasz,

Adam Mickiewicz University, Poland

Alok Arun,

Inter American University of Puerto

Rico, Barranquitas Campus,

United States

Avinash Mishra

Central Salt and Marine Chemicals

Research Institute (CSIR), India

Ravindra Pal Singh,

National Agri-Food Biotechnology

Institute, India

*Correspondence:

Thomas Wichard

Thomas.Wichard@uni-jena.de

Specialty section:

This article was submitted to

Aquatic Physiology,

a section of the journal

Frontiers in Marine Science

Received: 22 June 2020 Accepted: 24 November 2020

Published: 16 December 2020

Citation:

Ghaderiardakani F, Quartino ML and Wichard T (2020) Microbiome-Dependent Adaptation of Seaweeds Under Environmental

Stresses: A Perspective.

Front. Mar. Sci. 7:575228. doi: 10.3389/fmars.2020.575228
The microbiome of macroalgae facilitates their adaptation to environmental stress. As bacteria release algal growth and morphogenesis promoting factors (AGMPFs), which are necessary for the healthy development of macroalgae, bacteria play a crucial role in stress adaptation of bacterial-algal interactions. To better understand the level of macroalgal dependence on the microbiome under various stress factors such as light, temperature, salt, or micropollutants, we propose a reductionist analysis of a tripartite model system consisting of the axenic green alga U/va (Chlorophyta) reinfected with two essential bacteria. This analysis will allow us to decipher the stress response of each symbiont within this cross-kingdom interaction. The paper highlights studies on possible survival strategies embedded in cross-kingdom interactions that govern the stress adaptation, including general features of metabolic pathways in the macroalgal host or more specific features such as alterations in the composition and/or diversity of bacterial assemblages within the microbiome community. Additionally, we present some preliminary results regarding the effect of recently isolated bacteria from the Potter Cove, King George Island (Isla 25 de Mayo) in Antarctica, on the model system Ulva mutabilis Føyn purified gametes. The results indicate that coldadapted bacteria release AGMPFs, inducing cell differentiation, and cell division in purified cultures. We propose that microbiome engineering can be used to increase the adaptability of macroalgae to stressful situations with implications for, e.g., the sustainable management of (land-based) aquaculture systems.

Keywords: cross-kingdom interactions, holobiont ecology, green tide, macroalgae, microbiome, terrestrialization, Ulva mutabilis

\section{INTRODUCTION}

Microbiotas are recognized for their essential role in host health. Epibiotic biofilms, in particular, have the potential to control significant aspects of the biology and ecology of their hosts. Their composition and function may thus be essential for host health (Stratil et al., 2014). Moreover, it was suggested that the host could dynamically modulate its microbiota to adjust to the environment. This host-microbiota association is the subject of an emerging field of research that focuses 
on disease prevention based on treatments that restore or manipulate microbial communities (Simon et al., 2019). The entity comprised of the host and microbes, such as viruses and cellular microorganisms, is called holobiont (Zilber-Rosenberg and Rosenberg, 2008). Microbial symbionts can be constant or inconstant, can be vertically or horizontally transmitted, and can act in a context-dependent manner as parasitism, commensalism, or mutualism (Theis et al., 2016). Such properties enable microbial symbionts to participate in the adaptation and acclimation of the host.

To unify the different definitions of "stress" in algal literature, Borowitzka (2018) defined stress as "the disruption of homeostasis due to a stressor," and the stress response was defined as the changes in cell metabolism during acclimation that lead to the restoration of homeostasis. Acclimations are short-term physiological alterations that happen over a lifetime of the organism in response to transitory changes in environmental conditions (Borowitzka, 2018). In contrast, mechanisms underlying adaptive processes occur at the genomic level. They are inherited across generations and aid organismal adaptation to changing environments (Morgan-Kiss et al., 2006). When investigating the acclimation and adaptation processes in plants and algae, the entire holobiont, including the interactions between the host and its associated microbiome, should be considered. This paper discusses the role of the microbiome in algal adaptation to harsh conditions and mitigation of adverse effects such as anthropogenic pollutants. We propose a reductionist analysis of a tripartite model system consisting of the axenic green alga Ulva (Chlorophyta) re-infected with two essential bacteria to explore the possible survival strategies embedded in cross-kingdom interactions that are governing stress adaptations.

\section{Macroalgae and Bacteria Team Up to Adapt to Changing Ecosystems}

Growth, development, and distribution of seaweeds have been studied in many ecosystems concerning a variety of factors such as abiotic factors (e.g., temperature, salinity, desiccation, UVradiation), herbivory, diseases, and long-term climatic effects (Wahl et al., 2015; Qiu et al., 2019). Mycosporine-like amino acids are photoprotective substances produced by macroalgae that live in environments with high volumes of sunlight, usually marine environments (Hoyer et al., 2002; Han and Han, 2005). Cryoprotectants, in contrast, play a role in cold tolerance of macroalgae (Karsten et al., 1992). For example, betaine in bacteria induces cold tolerance by promoting the synthesis of membrane-fluidizing fatty acids. Therefore, it is tempting to speculate that protective compounds in algae might be provided by the bacteria.

As recently summarized by Gaitan-Espitia and Schmid (2020), the seaweed microbiome can influence the trait expression by controlling growth and morphogenesis (Goecke et al., 2010; Singh and Reddy, 2014; Wichard, 2015), acclimation and physiological responses of the host to environmental gradients (Dittami et al., 2016), the survival of propagules (Morris et al., 2016), competition among seaweeds by inhibiting the germination of algal spores (Egan et al., 2001), and rapid defense adaptation to bacterial epibionts and pathogens (Saha et al., 2016; Arnaud-Haond et al., 2017). Notably, the bacterium must show the ability to adapt to the changing conditions to support the host. Therefore, when macroalgae are exposed to environmental stress, they should no longer be considered as independent from the associated microbiota.

High-throughput omics techniques (metagenomics, metatranscriptomics, metabolomics, and metaproteomics) have been applied to decipher the eco-physiological function of the (core-) microbiome (Singh and Reddy, 2016). Spatial and temporal microbiome analysis revealed the most abundant phyla (Proteobacteria, Bacteroidetes, and Firmicutes) in macroalgae (Table 1), but only a few mechanisms and functions underlying the macroalgae-microbiota interactions were investigated in response to a changing environment. Two experimental approaches are currently used: (i) continuous microbiome analyses to monitor the entire time-lapse of the experiment, and (ii) application of model studies using tested axenic cultures. In both cases, the overall goal is to understand the holobiont functioning as a system of unraveling metabolic and signaling networks. For example, microbiome analysis revealed certain combinations of bacteria that are essential for adaptation of brown macroalgae (Ectocarpus, Ochrophyta) to changes in salinity (Dittami et al., 2011; Ritter et al., 2014; Kleinjan et al., 2017), and axenic cultures of Ulva (Chlorophyta) were used to test the specific activities of bacteria on algal growth and development (Spoerner et al., 2012; Ghaderiardakani et al., 2017).

The selected examples in the present paper are centered on the genus Ulva, a model organism particularly well suited for studies on interactions with bacteria because its axenic algal cultures are available. Ulva spp. are cosmopolitan, ecologically important green macroalgae inhabiting shallow seas (Kirkendale et al., 2013). They cause green tides worldwide and are thus increasingly important in coastal ecosystem management (Zhang et al., 2019). The genus is best known for its broad distribution in marine (fully saline), brackish, and freshwater ecosystems in tropical, temperate, and the less-studied polar regions (Figure 1A). A genetic toolbox was developed, and essential chemical mediators of the algae-bacteria interaction were identified (Joint et al., 2002; Tait et al., 2009; Oertel et al., 2015; De Clerck et al., 2018; Alsufyani et al., 2020).

\section{Chemically-Mediated Bacterial-Macroalgal Interactions}

Bacteria can be associated with the surface, the holdfast, or the chemical boundary layer of the alga in the surrounding water (Mieszkin et al., 2013; Egan et al., 2014; Wichard, 2015). Based on different scenarios, chemical compounds produced on macroalgal surface or its vicinity may present the primary factors driving the dynamic of bacterial communities within the network of algae-bacteria interactions (Lachnit et al., 2013; Kessler et al., 2018; Alsufyani et al., 2020; Burgunter-Delamare et al., 2020; Paix et al., 2020). 
TABLE 1 | Exemplary microbiome studies of green, brown, and red macroalgae sorted chronologically.

\begin{tabular}{|c|c|c|c|c|}
\hline Macroalgae & Origin & Objective or key message & $\begin{array}{l}\text { Change of } \\
\text { stressor/parameter }\end{array}$ & References \\
\hline Ulva australis & $\begin{array}{l}\text { Bare Island, La Perouse and } \\
\text { Shark Point, Clovelly, Australia }\end{array}$ & $\begin{array}{l}\text { Comparison of variability within the } U \text {. australis community of } \\
\text { epiphytic bacteria collected from two tidal pools. }\end{array}$ & Different tidal pool & Burke et al., 2011 \\
\hline $\begin{array}{l}\text { Caulerpa } \\
\text { racemosa }\end{array}$ & $\begin{array}{l}\text { Mediterranean Sea and } \\
\text { Southwestern Australia }\end{array}$ & $\begin{array}{l}\text { Deciphering the role of associated bacteria in adaptation } \\
\text { processes. Bacterial communities can be used as a useful tracer of } \\
\text { the origin of invasion. }\end{array}$ & Invasive species & Aires et al., 2013 \\
\hline $\begin{array}{l}\text { Caulerpa } \\
\text { taxifolia }\end{array}$ & $\begin{array}{l}\text { Port River and Moreton Bay, } \\
\text { Queensland, Australia }\end{array}$ & $\begin{array}{l}\text { Survey of warming effects and ocean acidification on algal growth } \\
\text { and associated bacterial communities. }\end{array}$ & $\begin{array}{l}\text { Warming and ocean } \\
\text { acidification }\end{array}$ & $\begin{array}{l}\text { Roth-Schulze et al., } \\
2018\end{array}$ \\
\hline Ulva rigida & Aveiro, aquaculture, Portugal & $\begin{array}{l}\text { The influence of integrated multi-trophic aquaculture (IMTA) settings } \\
\text { on the associated microbiome. Growth-promoting bacteria were } \\
\text { enriched in the aquaculture. }\end{array}$ & IMTA & Califano et al., 2020 \\
\hline $\begin{array}{l}\text { Laminaria } \\
\text { hyperborea }\end{array}$ & $\begin{array}{l}\text { Tekslo, Landro, Flatevossen, } \\
\text { Southwestern Norway }\end{array}$ & $\begin{array}{l}\text { To investigate the relationship between bacterial diversity with } \\
\text { bacterial secondary production and primary succession on kelp } \\
\text { surfaces. Bacterial diversity increases with the age of kelp surface. }\end{array}$ & Thallus survey & $\begin{array}{l}\text { Bengtsson et al., } \\
2012\end{array}$ \\
\hline $\begin{array}{l}\text { Fucus } \\
\text { vesiculosus }\end{array}$ & Baltic Sea, Germany & $\begin{array}{l}\text { Testing the effect of surface-available algal compounds on bacterial } \\
\text { settlement and community composition. }\end{array}$ & Thallus survey & Lachnit et al., 2013 \\
\hline $\begin{array}{l}\text { Fucus } \\
\text { vesiculosus }\end{array}$ & Baltic Sea, Germany & $\begin{array}{l}\text { Showing a seasonal and special difference in anti-settlement activity } \\
\text { of algal extracts. }\end{array}$ & Season & $\begin{array}{l}\text { Saha and Wahl, } \\
2013\end{array}$ \\
\hline $\begin{array}{l}\text { Fucus } \\
\text { vesiculosus }\end{array}$ & $\begin{array}{l}\text { Kiel Fjord, Western Baltic, } \\
\text { Germany }\end{array}$ & $\begin{array}{l}\text { Salinity is an essential factor in structuring alga-associated } \\
\text { epibacterial communities concerning composition and/or diversity. }\end{array}$ & Salinity & Stratil et al., 2014 \\
\hline $\begin{array}{l}\text { Ectocarpus } \\
\text { subulatus }\end{array}$ & $\begin{array}{l}\text { From different geographic } \\
\text { origins }\end{array}$ & $\begin{array}{l}\text { Host-microbe interactions as a driver of acclimation to salinity } \\
\text { gradients. Microbial communities can impact the acclimation and } \\
\text { physiological response of algae to different environments. }\end{array}$ & Salinity & Dittami et al., 2016 \\
\hline $\begin{array}{l}\text { Ectocarpus } \\
\text { subulatus }\end{array}$ & $\begin{array}{l}\text { Hopkins River Falls, Victoria, } \\
\text { Australia }\end{array}$ & $\begin{array}{l}\text { Providing a collection of cultivable E. subulatus-associated bacteria } \\
\text { as a valuable tool to study the algal holobiont and complement the } \\
\text { genomic tools available for the model Ectocarpus. }\end{array}$ & $\begin{array}{l}\text { Explorative study of } \\
\text { the microbiome }\end{array}$ & Kleinjan et al., 2017 \\
\hline $\begin{array}{l}\text { Sargassum } \\
\text { muticum }\end{array}$ & $\begin{array}{l}\text { Praia Norte and Praia do } \\
\text { Queimado, Portugal }\end{array}$ & $\begin{array}{l}\text { Study of the temporal and spatial variations in microbial } \\
\text { communities associated with the invasive brown seaweed } \\
\text { S. muticum. }\end{array}$ & Invasive species & $\begin{array}{l}\text { Serebryakova et al., } \\
2018\end{array}$ \\
\hline $\begin{array}{l}\text { Ectocarpus } \\
\text { subulatus }\end{array}$ & $\begin{array}{l}\text { Hopkins River Falls, Victoria, } \\
\text { Australia }\end{array}$ & $\begin{array}{l}\text { Providing a genomic resource of the associated microbiome for } \\
\text { comparative genomic analyses and evolutionary surveys. }\end{array}$ & $\begin{array}{l}\text { Explorative study of } \\
\text { the microbiome }\end{array}$ & Karimi et al., 2019 \\
\hline Delisea pulchra & Bare Island, Sydney, Australia & $\begin{array}{l}\text { Exploring the role of associated bacterial community in algal } \\
\text { disease. The complex shift in the community composition } \\
\text { associated with bleaching of } D \text {. pulchra and opportunistic } \\
\text { pathogens or scavengers. }\end{array}$ & Disease & $\begin{array}{l}\text { Fernandes et al., } \\
2012\end{array}$ \\
\hline $\begin{array}{l}\text { Porphyra } \\
\text { umbilicalis }\end{array}$ & Schoodic Point, United States & $\begin{array}{l}\text { Comparison of the bacterial community composition in field and } \\
\text { laboratory macroalgae and seasonal changes. Bacteroidetes were } \\
\text { the main phyla on field and laboratory blades. }\end{array}$ & Growth conditions & $\begin{array}{l}\text { Miranda et al., } \\
2013\end{array}$ \\
\hline Delisea pulchra & Long Bay, Sydney, Australia & $\begin{array}{l}\text { The microbial community could obtain or preserve functions to } \\
\text { sustain the health of its host. }\end{array}$ & Disease & $\begin{array}{l}\text { Zozaya-Valdés } \\
\text { et al., } 2017\end{array}$ \\
\hline $\begin{array}{l}\text { Asparagopsis } \\
\text { taxiformis }\end{array}$ & La Ciotat, France & $\begin{array}{l}\text { Investigating the coral-macroalga interaction. } \\
\text { No effects of the macroalga on coral health or metabolism, while } \\
\text { the contact interaction with the coral induced a change in the } \\
\text { macroalgal metabolomic fingerprint. }\end{array}$ & Effect of corals & Greff et al., 2017 \\
\hline
\end{tabular}

Employing a multi-omics approach on the thallus scale demonstrated that chemical production, which is mostly stimulated by the algal physiology, defines the microbial community structure and composition at the surface of individual thalli of Taonia atomaria. For example, higher amounts of sesquiterpenes and phosphatidylcholines were observed in the apical regions, whereas dimethylsulfoniopropionate (DMSP) and carotenoids were predominantly found at the basal parts of the thalli (Paix et al., 2020). The algal host might play an active role in the arrangement of bacterial communities, as shown for DMSP, which act as chemoattractant guiding bacteria toward released photosynthates (Kessler et al., 2018). Interestingly, the diversity and taxonomic composition of epiphytic microbial communities on the thallus of wild and aquaculture-grown $U$. rigida were significantly different from those in the surrounding seawater, indicating that Ulva modifies the environment to its preferences (Califano et al., 2020).

Symbiotic epiphytic bacteria affect many aspects of marine algal host fitness synergistically, including growth and morphogenesis. Green seaweeds, such as Ulvales, lose their typical morphology when grown under bacteria-free (axenic) conditions or in the absence of appropriate microbiome. Consequently, plantlets proliferate in an undifferentiated and callus-like morphotype (Spoerner et al., 2012; Wichard, 2015). Based on an analysis of $U$. mutabilis [recently reclassified to 
A

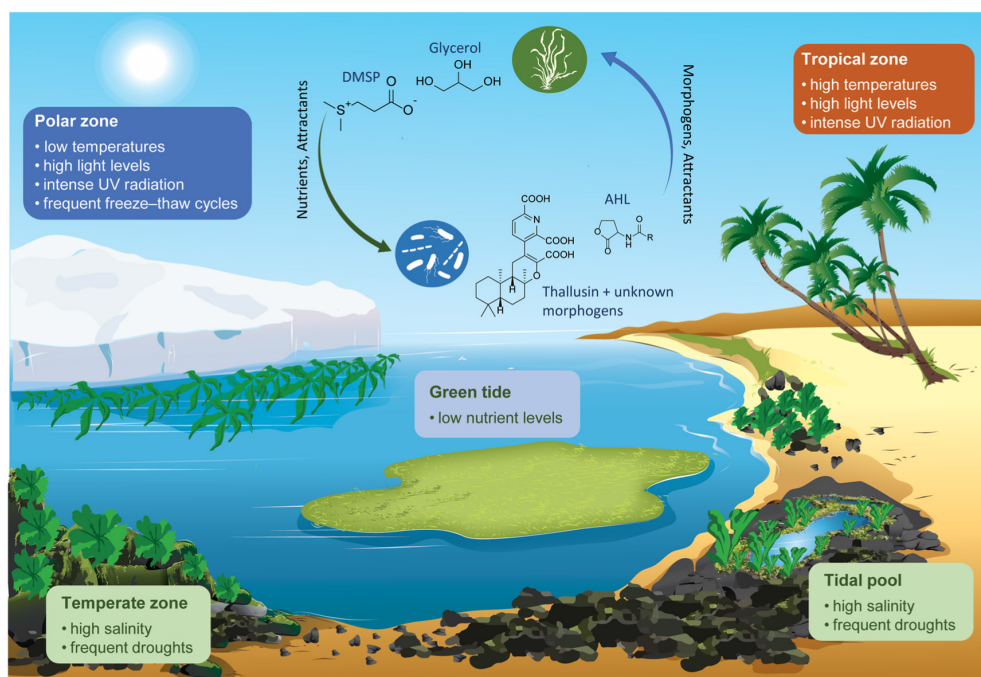

B

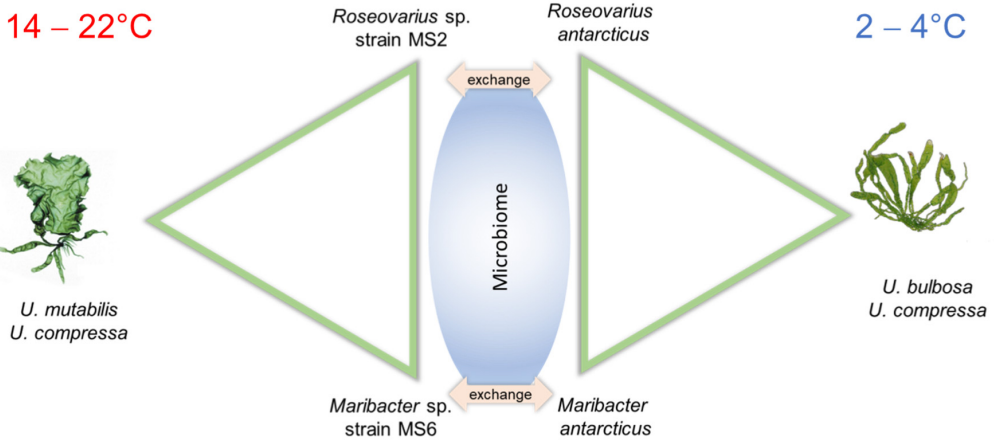

C
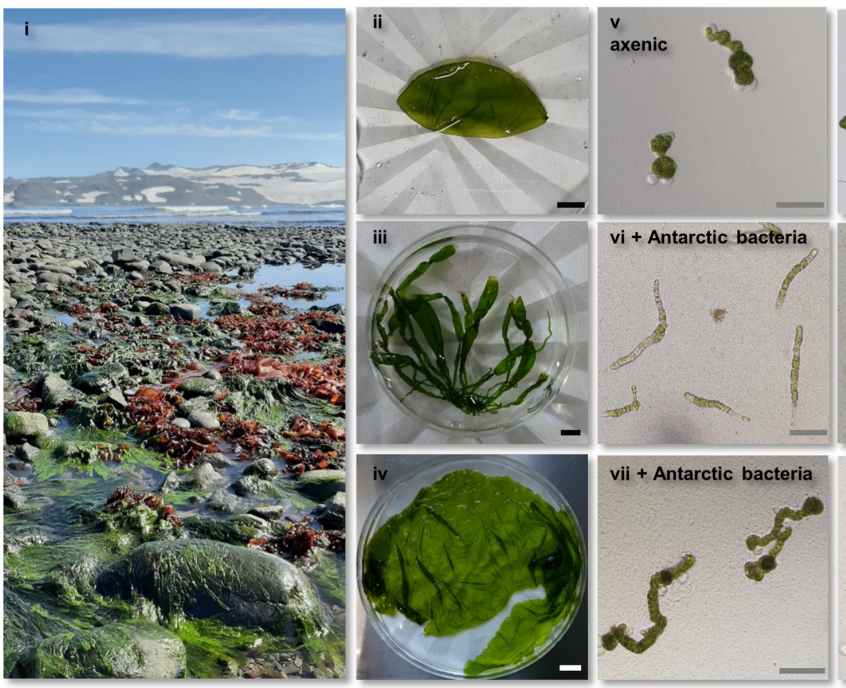

tripartite community

vi + Antarctic bacteria
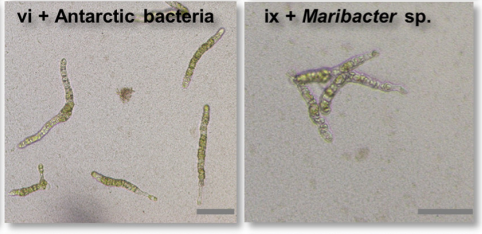

vii + Antarctic bacteria
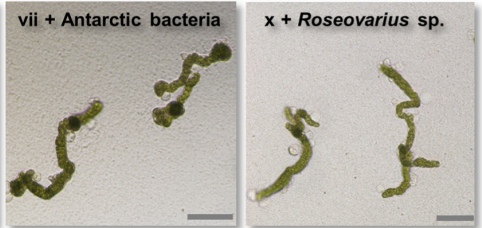

FIGURE 1 | (A) U/va is a cosmopolitan seaweed that inhabits a range of gradient ecosystems. The physiological mechanisms of niche adaptation of U/va to extreme environmental conditions, such as those in polar regions, that disrupt cellular activities in most organisms and the structure of its community are yet to be investigated in detail. A range of compounds has been identified that modulate the niche adaptation and modulate abiotic stresses. Amino acids, e.g., proline, and their derivatives such as betaine and zwitterionic metabolites, such as DMSP, are produced under cold stress. Morphogens (thallusin), attractants (DMSP, N-acyl homoserine lactones [AHLs with various acyl side chains R]) and nutrients (glycerol) mediate the bacteria-macroalgae interactions. (B) The "symbiotic toolkit" of U/va applies a reductionist strategy under controlled conditions to decipher the microbiome-dependent adaptation to environmental stimulus in Ulva. A designed microbiome can be tested in cross-exchange experiments using freshly isolated straits from Antarctica or reference strains such as Maribacter antarcticus (DSM 21422) and Roseovarius antarcticus (DSM 102249). (C) U/va spp. can preserve their growth, reproduction, and metabolic processes despite harsh environmental conditions, e.g., (i) in polar region in the Potter Cove on King George Island. Monostroma sp. (ii), Ulva sp. (iii), and Protomonostroma spp. (iv) were found in Antarctica in the summer of 2020. Associated bacteria from these green macroalgae release algal growth- and morphogenesis-promoting factors, which induce normal cell wall and rhizoid formation (vi) as well as cell division (vii) in axenic cultures (v) of U. mutabilis. Controls are shown (viii-x). Photographs (i-iv) were taken with permission from Fromm et al., 2020. 
U. compressa (Steinhagen et al., 2019)], these malformations could be partly or entirely relieved by complementing the culture medium with appropriate marine bacteria with at least two different functionalities to form a tripartite community of Ulva, Roseovarius sp., and Maribacter sp. (Spoerner et al., 2012; Grueneberg et al., 2016; Ghaderiardakani et al., 2017). The tripartite community can be used as a "symbiotic toolkit" to study host - microbiome interactions (Figure 1B). Within the chemosphere, these organisms interact with each other through chemical mediators such as AGMPFs, nutrients (photosynthates), and bacterial attractants (DMSP) (Figure 1B). Thallusin has been recently defined as the Maribacter-factor that triggers morphogenesis in U. mutabilis (Alsufyani et al., 2020) and was initially described for the development of Monostroma sp. (Chlorophyta) (Matsuo et al., 2005). Thallusin acts as a morphogen and induces cell differentiation, cell wall development, and rhizoid formation in $U$. mutabilis at concentrations in the picomole per liter range (Wichard, 2015; Alsufyani et al., 2020). For the release of thallusin and other chemical mediators, both the alga and the associated bacteria that provide those compounds must show an adequate intrinsic stress response. Host-microbe interactions can thus become the driver of acclimation to environmental changes (Dittami et al., 2016). Complementary to microbiome-wide approaches, we conclude that reductionist analyses focusing on one host and two microbes will pave the way to a better understanding of the core functioning of biotic interactions between macroalgae and bacteria under stress conditions. Cross-exchange experiments with bacteria under controlled conditions, as proposed in Figure 1B, will test the contribution of bacteria to algal adaptability.

\section{Upcoming Research Questions and Perquisites}

We hypothesize that macroalgae can react adequately to stress if its microbiome adapts to environmental changes to provide, e.g., the necessary AGMPFs that will help to withstand adverse effects. Although the algal microbiota is expected to change over time depending on abiotic and biotic environmental constraints, hostspecific traits must always be fulfilled to preserve the growth of Ulva spp.

Macroalgae might adapt to a changing environment through two main processes:

(i) by intrinsic changes in the algal metabolism caused by, for example, differential gene expression and metabolite production of compounds such as cryoprotective or photoprotective substances;

(ii) by extrinsic changes provided by the associated and stressadapted microbiome caused by its continuous support with AGMPFs and additional factors.

Thus, we raise the question: How do cooperative crosskingdom interactions contribute to stress adaptation?

\section{MICROBIOME-DEPENDENT RESPONSES OF MACROALGAE TO ENVIRONMENTAL STIMULI}

In the following section, we present four cases that provide evidence that the macroalgae-associated microbiome enables healthy growth under selected environmental changes. The microbiome can contribute to healthy algal development through its multiple functions, e.g., by adaptation to changes in temperature or salinity, detoxification, chemical defense, or terrestrialization.

\section{Cold Temperature Stress and Growth of Bacteria}

Marine macroalgae often experience remarkable fluctuations in temperature, both on a daily and seasonal scale (Raven and Geider, 1988; Davison et al., 1991; Davison and Pearson, 1996). Cold temperature refers to conditions that deviate substantially (negatively) from optimum growth temperatures for most vascular plant taxa and macroalgae. Cold-adapted plants can complete their life cycle at low, growth-restricting temperatures by either (i) exploiting the warmest period of an otherwise icy climate (season length restrictions) or (ii) growing and developing under prevailing cold conditions (Körner, 2016). Antarctic water temperatures are very stable throughout the year, and surface temperatures usually do not vary strongly throughout different seasons (Clarke, 1988). Cryoprotectants, used to protect biological tissue from freezing damage, may contribute to the adaptation of the algae to cold water in Antarctica. For instance, a shift to cold conditions (from 18 to $4^{\circ} \mathrm{C}$ ) induces a nearly threefold increase in the production of the zwitterion DMSP in U. mutabilis (Kessler et al., 2017) when compared with that produced by green macroalgae of the genera Ulothrix and Acrosiphonia (Karsten et al., 1992). Although thermosensors (such as the prion domain of EARLY FLOWERING 3) have been recently identified in the flowering plant Arabidopsis thaliana (Jung et al., 2020), the thermosensory mechanisms are still unknown in macroalgae.

Several studies have highlighted the features in bacteria associated with cold tolerance, such as synthesis of cold shock proteins, compatible solutes, and exopolysaccharides, as well as membrane modifications (Tribelli and López, 2018). Ulva compressa and related species are distributed worldwide, including in the coastal ecosystems of the Peninsula Antarctica (Gerlache Strait) and South Shetland Islands (Deception Island, King George Island), where water temperatures range seasonally between -1.8 and $2^{\circ} \mathrm{C}$ (Wiencke and Dieck, 1989, 1990; Clayton et al., 1997; Wiencke and Clayton, 2009). Here, the microbiome associated with these species needs to provide the functional traits necessary for algal growth under cold conditions.

Our results indicate that axenic gametes fail to grow at $2^{\circ} \mathrm{C}$, but in the presence of appropriate bacteria, they develop the normal morphotype (Figure 1C). The Mediterranean species $U$. compressa is likely to be able to adapt to the cold environment in the presence of psychrophilic bacteria that can deliver AGMPFs under severe cold conditions. Antarctic 
bacteria releasing AGMPFs have been recently isolated in the Potter Cove [King George Island (Isla 25 de Mayo), Antarctica] (Wichard et al., 2020). This collection of cultivable bacteria is a valuable tool to test the hypothesis for bacteria-dependent cold adaptation in Ulva.

\section{Linking the Microbiome Community Composition and Adaption of Macroalgae to Salinity Changes}

Osmotic acclimation in marine macroalgae, in response to changes in salinity, is a fundamental mechanism of salinity tolerance that conserves intracellular homeostasis (Jacob et al., 1991; Kirst and Wiencke, 1995) through the accumulation of organic solutes (Edwards et al., 1987; Karsten et al., 1991). Ectocarpus, a small filamentous brown alga, acclimates to the extreme environmental changes as it transitions from seawater to a freshwater medium through changes in the microbiome composition (Dittami et al., 2016). In their study, Dittami et al. (2016) showed that only the cultures of Ectocarpus that were not treated with antibiotic, and thereby were associated with a microbiome, were able to survive in a low-salinity culture medium. Their study confirmed the important role of associated bacteria in low-salinity tolerance and adaptive capacity of Ectocarpus to extreme changes in environmental conditions such as the transition to freshwater. As unavoidable consequences of global warming, melting glaciers and ice sheets release freshwater and reduce the salinity of the surrounding water. Thus, variations in symbiotic strategies with the potential to moderate acclimation and adaptation processes become vital for living organisms in these areas. These strategies can be explored and revealed by employing a "symbiotic toolkit" using a defined interaction between an organism (preferably a model-organism) and bacteria.

\section{Role of Bacteria in Macroalgal Tolerance to Adverse Metal Concentrations}

The ability of macroalgae to propagate in metal-polluted ecosystems depends on many mechanisms such as exclusion mechanism (e.g., Cd), internal detoxification (e.g., Cu), or metal transformation (e.g., $\mathrm{Hg}$ ) as well as the production of extracellular binding polypeptides such as cysteine-rich metallothionein (Peña-Salamanca et al., 2012). The unique biochemical and genetic features of heavy metal resistance in bacteria, as well as the cellular mechanisms involved in controlling the heavy metals via immobilization of metal ions into biologically unavailable species, have been extensively studied (Barkay et al., 2003).

Macroalgae and bacteria may share a variety of strategies for detoxification of metals at high concentrations, and thus, macroalgae-bacteria interactions can be involved in detoxification to benefit the macroalgae. For instance, the marine Bacillus spp. or Pseudomonas aeruginosa remove $\mathrm{Hg}$ through volatilization and $\mathrm{Cd}$ and $\mathrm{Pb}$ through their entrapment in the extracellular polymeric substance (De et al., 2008). The natural bacterial consortium in the red algae Bostrychia calliptera (Rhodomelaceae) contributes to chromium removal and thus potentially to the host fitness (Rengifo-Gallego et al., 2012). These transformation processes reduce the metal load in the medium and assist in algal growth. In exchange for detoxification of the algal chemosphere, the bacteria might receive higher amounts of photosynthates, the production of which might even be increased through bacteria-released AGMPFs.

There is a presumably concerted action of heavy metal detoxification by Ulva (Villares et al., 2001) and its associated microorganisms. Both bacteria and macroalgae can efficiently remove heavy metals such as $\mathrm{Hg}, \mathrm{Cd}, \mathrm{Pb}$, or $\mathrm{Zn}$ from the seawater and even grow in media with high metal concentrations $(25 \mathrm{mg}$ $\left.\mathrm{L}^{-1}\right)$. Moreover, there is evidence that in Ulva the morphogenetic activity of thallusin, an AGMPF that can scavenge Fe or other metal ions from the environment, is linked with intracellular Fe homeostasis (Alsufyani et al., 2020). The use of axenic cultures or manipulated microbiomes will help to understand the role of bacteria and macroalgae in detoxification and essential trace metal recruitment.

\section{Green Tides of Ulva Favor Nitrate Depletion and Growth of Diazotrophic Bacteria}

Macroalgal blooms of Ulva spp. often occur in coastal areas with high nutrient influx, causing dramatic changes in biogeochemical cycling. Few studies have explored the effects of macroalgal blooms on marine bacteria regarding the nutrient cycles in coastal waters. Zhang et al. (2015) demonstrated that the copy number of the nitrogen-fixing nitrogenase-encoding nifH gene was inversely proportional to the ammonium concentration, amount of dissolved inorganic nitrogen, and stoichiometric ratios of N:P and N:Si in the Yellow Sea (China). Macroalgal blooms can thus affect the community composition of the microbiome during an algal bloom (Zhang et al., 2015). Ulva provides carbon sources to the habitat, while depleting the nitrogen sources. Consequently, macroalgal blooms favor heterotrophic diazotrophic bacteria in coastal surface waters in the Yellow Sea (China).

\section{PERSPECTIVES IN MICROBIOME ENGINEERING}

Perturbations to microbiomes cause undesirable phenotypes in macroalgae, leading to disorders in algal development (Wichard, 2015). Engineering of microbiomes can be used to modify structures of the microbiota and restore ecological balance (Foo et al., 2017). Consequently, microbiome engineering can be considered to address fundamental research questions and to increase algal productivity. The first applications of microbiome engineering under laboratory conditions demonstrated that the photosynthates (e.g., glycerol) are changing with the microbiome (Polikovsky et al., 2020).

Interestingly, the association between plants and microorganisms is known to be ancient (Vandenkoornhuyse et al., 2015). The conquest of land by plants is assumed to have relied on the ability of algae to establish symbiotic interactions (Delaux et al., 2013; Field et al., 2015). For example, the 
beneficial associations between the earliest land plants and arbuscular mycorrhizal fungi are believed to be involved in the terrestrialization process and had accompanied the evolution and diversification of plant phototrophs (Vandenkoornhuyse et al., 2015; Fürst-Jansen et al., 2020). These symbiotic strategies are still at work today; for instance, Ulva depends on morphogenesisinducing bacteria.

At present, the established tripartite community of UlvaRoseovarius-Maribacter, which is made up of strictly sterile $U$. mutabilis cultures, is a model system that allows us to create controlled conditions in the laboratory. Moreover, it is very much desirable to establish similar cultivation systems for red and brown macroalgae as well. Also, assessing the role of potential endophytic bacteria should be considered in macroalgal stress adaptation in future studies.

Finally, a safety note, algae transplantation experiments together with microbiome engineering must not be carried out in the algae habitat in nature due to unforeseen risks for biological safety.

In summary, Ulva serves as a unique model system to study the requirements of associated bacteria to withstand environmental stresses and to develop a multicellular organism. Tools in phycology and genetics can be combined with systems biology to increase our understanding of the mutualistic interaction of the holobiont in adaptation processes. Thus, the metabolic complementarity of host and symbionts could be an excellent marker for beneficial interactions as outlined by Burgunter-Delamare et al. (2020). A combination of "putting pieces apart" (reductionist biology) and "putting pieces together" (systems biology) seems thus to be the most promising approach to understanding the evolution of system properties in the phycosphere.

\section{REFERENCES}

Aires, T., Serrão, E. A., Kendrick, G., Duarte, C. M., and Arnaud-Haond, S. (2013). Invasion is a community affair: Clandestine followers in the bacterial community associated to green algae, Caulerpa racemosa, track the invasion source. PLoS One 8:e68429. doi: 10.1371/journal.pone.0068429

Alsufyani, T., Califano, G., Deicke, M., Grueneberg, J., Weiss, A., Engelen, A. H., et al. (2020). Macroalgal-bacterial interactions: identification and role of thallusin in morphogenesis of the seaweed Ulva (Chlorophyta). J. Exp. Bot. 71, 3340-3349. doi: 10.1093/jxb/eraa066

Arnaud-Haond, S., Aires, T., Candeias, R., Teixeira, S. J. L., Duarte, C. M., Valero, M., et al. (2017). Entangled fates of holobiont genomes during invasion: nested bacterial and host diversities in Caulerpa taxifolia. Mol. Ecol. 26, 2379-2391. doi: $10.1111 / \mathrm{mec} .14030$

Barkay, T., Miller, S. M., and Summers, A. O. (2003). Bacterial mercury resistance from atoms to ecosystems. FEMS Microbiol. Rev. 27, 355-384. doi: 10.1016/ s0168-6445(03)00046-9

Bengtsson, M. M., Sjøtun, K., Lanzén, A., and Øvreås, L. (2012). Bacterial diversity in relation to secondary production and succession on surfaces of the kelp Laminaria hyperborea. ISME J. 6, 2188-2198. doi: 10.1038/ismej.2012.67

Borowitzka, M. A. (2018). The 'stress' concept in microalgal biology-homeostasis, acclimation and adaptation. J. Appl. Phycol. 30, 2815-2825. doi: 10.1007/ s10811-018-1399-0

Burgunter-Delamare, B., Kleinjan, H., Frioux, C., Fremy, E., Wagner, M., Corre, E., et al. (2020). Metabolic complementarity between a brown alga and associated cultivable bacteria provide indications of beneficial interactions. Front. Mar. Sci. 7:85. doi: 10.3389/fmars.2020.00085

\section{DATA AVAILABILITY STATEMENT}

The original contributions presented in the study are included in the article/supplementary material, further inquiries can be directed to the corresponding author/s.

\section{AUTHOR CONTRIBUTIONS}

FG and TW conceived, designed, and wrote the manuscript. FG, MQ, and TW performed the experiments at the Carlini Station [Potter Cove, King George Island (Isla 25 de Mayo), Antarctica] in 2020. All authors contributed to the final version of the manuscript.

\section{FUNDING}

This work was supported by the Deutsche Forschungsgemeinschaft (DFG, German Research Foundation) in the framework of the priority program (SPP 1158) "Antarctic Research with comparative investigations in Arctic ice areas" (424256657, FG, and TW) and of SFB 1127/2 ChemBioSys (239748522, TW). MQ was funded by ANPCyT-DNA PICT 2017-2691.

\section{ACKNOWLEDGMENTS}

We would like to acknowledge all those colleagues whose work could not be cited due to space constraints. We thank the Carlini Station crews and Georg Pohnert (University Jena) for their great support.

Burke, C., Steinberg, P., Rusch, D., Kjelleberg, S., and Thomas, T. (2011). Bacterial community assembly based on functional genes rather than species. Proc. Nat. Acad. Sci. U.S.A. 108, 14288-14293. doi: 10.1073/pnas.1101591108

Califano, G., Kwantes, M., Abreu, M. H., Costa, R., and Wichard, T. (2020). Cultivating the macroalgal holobiont: effects of integrated multi-trophic aquaculture on the microbiome of Ulva rigida (Chlorophyta). Front. Mar. Sci. 7:52. doi: $10.3389 /$ fmars.2020.00052

Clarke, A. (1988). Seasonality in the antarctic marine environment. Comp. Biochem. Physiol. B Comp. Biochem. 90, 461-473. doi: 10.1016/0305-0491(88) 90285-4

Clayton, M. N., Wiencke, C., and Klöser, H. (1997). New records of temperate and sub-Antarctic marine benthic macroalgae from Antarctica. Polar Biol. 17, 141-149. doi: 10.1007/s003000050116

Davison, I. R., Greene, R. M., and Podolak, E. J. (1991). Temperature acclimation of respiration and photosynthesis in the brown alga Laminaria saccharina. Mar. Biol. 110, 449-454. doi: 10.1007/bf01344363

Davison, I. R., and Pearson, G. A. (1996). Stress tolerance in intertidal seaweeds. J. Phycol. 32, 197-211. doi: 10.1111/j.0022-3646.1996.00197.x

De, J., Ramaiah, N., and Vardanyan, L. (2008). Detoxification of toxic heavy metals by marine bacteria highly resistant to mercury. Mar. Biotechnol. (N. Y.) 10, 471-477. doi: 10.1007/s10126-008-9083-z

De Clerck, O., Kao, S. M., Bogaert, K. A., Blomme, J., Foflonker, F., Kwantes, M., et al. (2018). Insights into the evolution of multicellularity from the sea lettuce genome. Curr. Biol. 28, 2921-2933.

Delaux, P. M., Séjalon-Delmas, N., Bécard, G., and Ané, J. M. (2013). Evolution of the plant-microbe symbiotic 'toolkit'. Trends Plant Sci. 18, 298-304. doi: 10.1016/j.tplants.2013.01.008 
Dittami, S., Proux, C., Rousvoal, S., Peters, A., Cock, J., Coppee, J.-Y., et al. (2011). Microarray estimation of genomic inter-strain variability in the genus Ectocarpus (Phaeophyceae). BMC Mol. Biol. 12:2. doi: 10.1186/1471-2199-12-2

Dittami, S. M., Duboscq-Bidot, L., Perennou, M., Gobet, A., Corre, E., Boyen, C., et al. (2016). Host-microbe interactions as a driver of acclimation to salinity gradients in brown algal cultures. ISME J. 10, 51-63. doi: 10.1038/ismej. 2015.104

Edwards, D. M., Reed, R. H., Chudek, J. A., Foster, R., and Stewart, W. D. P. (1987). Organic solute accumulation in osmotically stressed Enteromorpha intestinalis. Mar. Biol. 95, 583-592. doi: 10.1007/bf00393102

Egan, S., Fernandes, N. D., Kumar, V., Gardiner, M., and Thomas, T. (2014). Bacterial pathogens, virulence mechanism and host defence in marine macroalgae. Environ. Microbiol. 16, 925-938. doi: 10.1111/1462-2920.12288

Egan, S., James, S., Holmström, C., and Kjelleberg, S. (2001). Inhibition of algal spore germination by the marine bacterium Pseudoalteromonas tunicata. FEMS Microbiol. Ecol. 35, 67-73. doi: 10.1111/j.1574-6941.2001.tb00789.x

Fernandes, N., Steinberg, P., Rusch, D., Kjelleberg, S., and Thomas, T. (2012). Community structure and functional gene profile of bacteria on healthy and diseased thalli of the red seaweed Delisea pulchra. PLoS One 7:e50854. doi: 10.1371/journal.pone.0050854

Field, K. J., Pressel, S., Duckett, J. G., Rimington, W. R., and Bidartondo, M. I. (2015). Symbiotic options for the conquest of land. Trends Ecol. Evol. 30, 477-486. doi: 10.1016/j.tree.2015.05.007

Foo, J. L., Ling, H., Lee, Y. S., and Chang, M. W. (2017). Microbiome engineering: current applications and its future. Biotechnol. J. 12:10. doi: 10.1002/biot. 201600099

Fromm, T., Oberdieck, C., Matz, T., and Wesche, C. (2020). Expeditions to Antarctica: ANT-Land 2019/20 Neumayer Station III, Kohnen Station, Flight Operations and Field Campaigns. Reports on Polar and Marine Research, Bremerhaven, Alfred Wegener Institute for Polar and Marine Research, $745,118$.

Fürst-Jansen, J. M. R., De Vries, S., and De Vries, J. (2020). Evo-physio: on stress responses and the earliest land plants. J. Exp. Bot. 11, 3254-3269. doi: 10.1093/ jxb/eraa007

Gaitan-Espitia, J. D., and Schmid, M. (2020). "Diversity and functioning of Antarctic seaweed microbiomes," in Anatarctic seaweds, eds I. Gómez, and P. Huovinen (London: Springer Nature), 279-291. doi: 10.1007/978-3-03039448-6_14

Ghaderiardakani, F., Coates, J. C., and Wichard, T. (2017). Bacteria-induced morphogenesis of Ulva intestinalis and Ulva mutabilis (Chlorophyta): a contribution to the lottery theory. FEMS Microbiol. Ecol. 93:fix094. doi: 10.1093/ femsec/fix094

Goecke, F., Labes, A., Wiese, J., and Imhoff, J. F. (2010). Chemical interactions between marine macroalgae and bacteria. Mar. Ecol. Progr. Ser. 409, 267-299. doi: $10.3354 /$ meps08607

Greff, S., Aires, T., Serrão, E. A., Engelen, A. H., Thomas, O. P., and Pérez, T. (2017). The interaction between the proliferating macroalga Asparagopsis taxiformis and the coral Astroides calycularis induces changes in microbiome and metabolomic fingerprints. Sci. Rep. 7:42625. doi: 10.1038/srep42625

Grueneberg, J., Engelen, A. H., Costa, R., and Wichard, T. (2016). Macroalgal morphogenesis induced by waterborne compounds and bacteria in coastal seawater. PLoS One 11:e0146307. doi: 10.1371/journal.pone.0146307

Han, Y.-S., and Han, T. (2005). UV-B induction of UV-B protection in Ulva pertusa (Chlorophyta). J. Phycol. 41, 523-530. doi: 10.1111/j.1529-8817.2005.00072.x

Hoyer, K., Karsten, U., and Wiencke, C. (2002). MAA synthesis and accumulation in polar macroalgae are controlled by abiotic factors. J. Phycol. 38, 17-17. doi: 10.1046/j.1529-8817.38.s1.50.x

Jacob, A., Kirst, G. O., Wiencke, C., and Lehmann, H. (1991). Physiological responses of the antarctic green alga Prasiola crispa ssp antarctica to salinity stress. J. Plant Physiol. 139, 57-62. doi: 10.1016/s0176-1617(11)80165-3

Joint, I., Tait, K., Callow, M. E., Callow, J. A., Milton, D., Williams, P., et al. (2002). Cell-to-cell communication across the prokaryote eukaryote boundary. Science 298:1207. doi: 10.1126/science. 1077075

Jung, J.-H., Barbosa, A. D., Hutin, S., Kumita, J. R., Gao, M., Derwort, D., et al. (2020). A prion-like domain in ELF3 functions as a thermosensor in Arabidopsis. Nature 585, 256-260. doi: 10.1038/s41586-020-2644-7

Karimi, E., Geslain, E., Kleinjan, H., Tanguy, G., Legeay, E., Corre, E., et al. (2019). Genome sequences of 72 bacterial strains isolated from Ectocarpus subulatus: a resource for algal microbiology. Genome Biol. Evol. 12, 3647-3655. doi: $10.1093 / \mathrm{gbe} / \mathrm{evz} 278$

Karsten, U., Wiencke, C., and Kirst, G. O. (1991). The effect of salinity changes upon the physiology of eulittoral green macroalgae from antarctica and southern Chile. J. Exp. Bot. 42, 1533-1539. doi: 10.1093/jxb/42.12.1533

Karsten, U., Wiencke, C., and Kirst, G. O. (1992). Dimethylsulphoniopropionate (DMSP) accumulation in green macroalgae from polar to temperate regions interactive effects of light versus salinity and light versus temperature. Polar Biol. 12, 603-607.

Kessler, R. W., Crecelius, A. C., Schubert, U. S., and Wichard, T. (2017). In situ monitoring of molecular changes during cell differentiation processes in marine macroalgae through mass spectrometric imaging. Anal. Bioanal. Chem. 409, 4893-4903. doi: 10.1007/s00216-017-0430-7

Kessler, R. W., Weiss, A., Kuegler, S., Hermes, C., and Wichard, T. (2018). Macroalagal-bacterial interactions: role of dimethylsulfoniopropionate in microbial gardening by Ulva (Chlorophyta). Mol. Ecol. 27, 1808-1819. doi: $10.1111 /$ mec. 14472

Kirkendale, L., Saunders, G. W., and Winberg, P. (2013). A molecular survey of Ulva (Chlorophyta) in temperate Australia reveals enhanced levels of cosmopolitanism. J. Phycol. 49, 69-81. doi: 10.1111/jpy.12016

Kirst, G. O., and Wiencke, C. (1995). Ecophysiology of polar algae. J. Phycol. 31, 181-199. doi: 10.1111/j.0022-3646.1995.00181.x

Kleinjan, H., Jeanthon, C., Boyen, C., and Dittami, S. M. (2017). Exploring the cultivable Ectocarpus microbiome. Front. Microbiol. 8:2456. doi: 10.3389/fmicb. 2017.02456

Körner, C. (2016). Plant adaptation to cold climates. F1000Res. 5:F1000. doi: 10. 12688/f1000research.9107.1

Lachnit, T., Fischer, M., Kuenzel, S., Baines, J. F., and Harder, T. (2013). Compounds associated with algal surfaces mediate epiphytic colonization of the marine macroalga Fucus vesiculosus. Fems Microbiol. Ecol. 84, 411-420. doi: 10.1111/1574-6941.12071

Matsuo, Y., Imagawa, H., Nishizawa, M., and Shizuri, Y. (2005). Isolation of an algal morphogenesis inducer from a marine bacterium. Science 307:1598. doi: $10.1126 /$ science. 1105486

Mieszkin, S., Callow, M. E., and Callow, J. A. (2013). Interactions between microbial biofilms and marine fouling algae: a mini review. Biofouling 29, 1097-1113. doi: 10.1080/08927014.2013.828712

Miranda, L. N., Hutchison, K., Grossman, A. R., and Brawley, S. H. (2013). Diversity and abundance of the bacterial community of the red macroalga Porphyra umbilicalis: did bacterial farmers produce macroalgae? PLoS One 8:e58269. doi: 10.1371/journal.pone.0058269

Morgan-Kiss, R. M., Priscu, J. C., Pocock, T., Gudynaite-Savitch, L., and Huner, N. P. A. (2006). Adaptation and acclimation of photosynthetic microorganisms to permanently cold environments. Microbiol. Mol. Biol. Rev. 70, 222-252. doi: $10.1128 / \mathrm{mmbr} .70 .1 .222-252.2006$

Morris, M. M., Haggerty, J. M., Papudeshi, B. N., Vega, A. A., Edwards, M. S., and Dinsdale, E. A. (2016). Nearshore pelagic microbial community abundance affects recruitment success of giant kelp, Macrocystis pyrifera. Front. Microbiol. 7:1800.

Oertel, W., Wichard, T., and Weissgerber, A. (2015). Transformation of Ulva mutabilis (Chlorophyta) by vector plasmids integrating into the genome. J. Phycol. 51, 963-979. doi: 10.1111/jpy.12336

Paix, B., Carriot, N., Barry-Martinet, R., Greff, S., Misson, B., Briand, J.-F., et al. (2020). A multi-omics analysis suggests links between the differentiated surface metabolome and epiphytic microbiota along the thallus of a mediterranean seaweed holobiont. Front. Microbiol. 11:494. doi: 10.3389/fmicb.2020.00494

Peña-Salamanca, E., Rengifo, A. L., and Campo, N. B. (2012). "Detoxification mechanisms of heavy metals by algal-bacteria consortia," in Handbook of Marine Macroalgae, ed. S. K. Kim (Hoboken, NJ: Wiley Online Books), 441450. doi: 10.1002/9781119977087.ch28

Polikovsky, M., Califano, G., Dunger, N., Wichard, T., and Golberg, A. (2020). Engineering bacteria-seaweed symbioses for modulating the photosynthate content of Ulva (Chlorophyta): significant for the feedstock of bioethanol production. Algal Res. 49:101945. doi: 10.1016/j.algal.2020.101945

Qiu, Z., Coleman, M. A., Provost, E., Campbell, A. H., Kelaher, B. P., Dalton, S. J., et al. (2019). Future climate change is predicted to affect the microbiome and condition of habitat-forming kelp. Proc. Biol. Sci. 286:20181887. doi: 10.1098/ rspb.2018.1887 
Raven, J. A., and Geider, R. J. (1988). Temperature and algal growth. New Phytol. 110, 441-461.

Rengifo-Gallego, A. L., Peña-Salamanca, E., and Benitez-Campo, N. (2012). Efecto de la asociación alga-bacteria Bostrychia calliptera (Rhodomelaceae) en el porcentaje de remoción de cromo en laboratorio [The effect of chromium removal by algae-bacteria Bostrychia calliptera (Rhodomelaceae) consortia under laboratory conditions]. Rev Biol Trop. 60, 1055-1064.

Ritter, A., Dittami, S., Goulitquer, S., Correa, J., Boyen, C., Potin, P., et al. (2014). Transcriptomic and metabolomic analysis of copper stress acclimation in Ectocarpus siliculosus highlights signaling and tolerance mechanisms in brown algae. BMC Plant Biol. 14:116. doi: 10.1186/1471-2229-14-116

Roth-Schulze, A. J., Thomas, T., Steinberg, P., Deveney, M. R., Tanner, J. E., Wiltshire, K. H., et al. (2018). The effects of warming and ocean acidification on growth, photosynthesis, and bacterial communities for the marine invasive macroalga Caulerpa taxifolia. Limnol. Oceanogr. 63, 459-471. doi: 10.1002/lno. 10739

Saha, M., and Wahl, M. (2013). Seasonal variation in the antifouling defence of the temperate brown alga Fucus vesiculosus. Biofouling 29, 661-668. doi: 10.1080/08927014.2013.795953

Saha, M., Wiese, J., Weinberger, F., and Wahl, M. (2016). Rapid adaptation to controlling new microbial epibionts in the invaded range promotes invasiveness of an exotic seaweed. J. Ecol. 104, 969-978. doi: 10.1111/1365-2745.12590

Serebryakova, A., Aires, T., Viard, F., Serrão, E. A., and Engelen, A. H. (2018). Summer shifts of bacterial communities associated with the invasive brown seaweed Sargassum muticum are location and tissue dependent. PLoS One 13:e206734. doi: 10.1371/journal.pone.0206734

Simon, J.-C., Marchesi, J. R., Mougel, C., and Selosse, M.-A. (2019). Hostmicrobiota interactions: from holobiont theory to analysis. Microbiome 7:5. doi: 10.1186/s40168-019-0619-4

Singh, R. P., and Reddy, C. R. K. (2014). Seaweed-microbial interactions: key functions of seaweed-associated bacteria. FEMS Microbiol. Ecol. 88, 213-230. doi: 10.1111/1574-6941.12297

Singh, R. P., and Reddy, C. R. K. (2016). Unraveling the functions of the macroalgal microbiome. Front. Microbiol. 6:1488. doi: 10.3389/fmicb.2015.01488

Spoerner, M., Wichard, T., Bachhuber, T., Stratmann, J., and Oertel, W. (2012). Growth and thallus morphogenesis of Ulva mutabilis (Chlorophyta) depends on a combination of two bacterial species excreting regulatory factors. J. Phycol. 48, 1433-1447. doi: 10.1111/j.1529-8817.2012.01231.x

Steinhagen, S., Barco, A., Wichard, T., and Weinberger, F. (2019). Conspecificity of the model organism Ulva mutabilis and Ulva compressa (Ulvophyceae, Chlorophyta). J. Phycol. 55, 25-36. doi: 10.1111/jpy.12804

Stratil, S. B., Neulinger, S. C., Knecht, H., Friedrichs, A. K., and Wahl, M. (2014). Salinity affects compositional traits of epibacterial communities on the brown macroalga Fucus vesiculosus. FEMS Microbiol. Ecol. 88, 272-279. doi: 10.1111/ 1574-6941.12292

Tait, K., Williamson, H., Atkinson, S., Williams, P., Camara, M., and Joint, I. (2009). Turnover of quorum sensing signal molecules modulates crosskingdom signalling. Environ. Microbiol. 11, 1792-1802. doi: 10.1111/j.14622920.2009.01904.x

Theis, K. R., Dheilly, N. M., Klassen, J. L., Brucker, R. M., Baines, J. F., Bosch, T. C. G., et al. (2016). Getting the hologenome concept right: an ecoevolutionary framework for hosts and their microbiomes. mSystems 1:e0002816. doi: $10.1128 / \mathrm{mSystems.00028-16}$
Tribelli, P. M., and López, N. I. (2018). Reporting key features in cold-adapted bacteria. Life (Basel) 8:8. doi: 10.3390/life8010008

Vandenkoornhuyse, P., Quaiser, A., Duhamel, M., Le Van, A., and Dufresne, A. (2015). The importance of the microbiome of the plant holobiont. New Phytol. 206, 1196-1206. doi: 10.1111/nph.13312

Villares, R., Puente, X., and Carballeira, A. (2001). Ulva and Enteromorpha as indicators of heavy metal pollution. Hydrobiologia 462, 221-232.

Wahl, M., Molis, M., Hobday, A. J., Dudgeon, S., Neumann, R., Steinberg, P., et al. (2015). The responses of brown macroalgae to environmental change from local to global scales: direct versus ecologically mediated effects. Perspect. Phycol. 2, 11-29. doi: 10.1127/pip/2015/0019

Wichard, T. (2015). Exploring bacteria-induced growth and morphogenesis in the green macroalga order Ulvales (Chlorophyta). Front. Plant Sci. 6:86.

Wichard, T., Ghaderiardakani, F., Zimmermann, J., Karsten, U., Grossart, H.P., and Livenets, A. (2020). "Biodiversity and adaptation of polar algae and their interactions with symbionts and parasites in a changing environment," in Reports on Polar and Marine Research, Vol. 745, eds T. Fromm, C. Oberdieck, T. Matz, and C. Wesche (Bremerhaven: Alfred Wegener Institute for Polar and Marine Research), 93-103.

Wiencke, C., and Clayton, M. N. (2009). Biology of polar benthic algae Introduction. Bot. Mar. 52, 479-481. doi: 10.1515/bot.2009.083

Wiencke, C., and Dieck, I. T. (1989). Temperature requirements for growth and temperature tolerance of macroalgae endemic to the antarctic region. Mar. Ecol. Prog. Ser. 54, 189-197. doi: 10.3354/meps054189

Wiencke, C., and Dieck, I. T. (1990). Temperature requirements for growth and survival of macroalgae from Antarctica and Southern Chile. Mar. Ecol. Prog. Ser. 59, 157-170. doi: 10.3354/meps059157

Zhang, W. Z., Wang, L., Chen, L., Shen, H., and Chen, J. (2019). Proliferation of filamentous green algae along with submerged macrophytes planting, and the role of microbe. Ecol. Eng. 139:40. doi: 10.1016/j.ecoleng.2019. 07.040

Zhang, X., Song, Y., Liu, D., Keesing, J. K., and Gong, J. (2015). Macroalgal blooms favor heterotrophic diazotrophic bacteria in nitrogen-rich and phosphoruslimited coastal surface waters in the Yellow Sea. Estuar. Coast. Shelf Sci. 163, 75-81. doi: 10.1016/j.ecss.2014.12.015

Zilber-Rosenberg, I., and Rosenberg, E. (2008). Role of microorganisms in the evolution of animals and plants: the hologenome theory of evolution. FEMS Microbiol. Rev. 32, 723-735. doi: 10.1111/j.1574-6976.2008.00123.x

Zozaya-Valdés, E., Roth-Schulze, A. J., Egan, S., and Thomas, T. (2017). Microbial community function in the bleaching disease of the marine macroalgae Delisea pulchra. Environ. Microbiol. 19, 3012-3024. doi: 10.1111/1462-2920.1 3758

Conflict of Interest: The authors declare that the research was conducted in the absence of any commercial or financial relationships that could be construed as a potential conflict of interest.

Copyright $\odot 2020$ Ghaderiardakani, Quartino and Wichard. This is an open-access article distributed under the terms of the Creative Commons Attribution License $(C C B Y)$. The use, distribution or reproduction in other forums is permitted, provided the original author(s) and the copyright owner(s) are credited and that the original publication in this journal is cited, in accordance with accepted academic practice. No use, distribution or reproduction is permitted which does not comply with these terms. 